\title{
"By Instruments her Powers Appeare": Music and Authority in the Reign of Queen Elizabeth I
}

\author{
by KATHERINE BUTLER
}

\begin{abstract}
Queen Elizabeth I's musical talents and the elaborate music of her courtly entertainments are widely acknowledged. However, while the effect of Elizabeth's gender on her authority as a ruler has been the subject of much historical research, the impact of this musical activity on the creation and representation of her authority has not been recognized. Gender stereotypes were both exploited and subverted as music became a symbol and tool of Elizabeth's queenship. Poets and courtiers drew inspiration from Elizabeth's music-making, combining traditional notions of the erotic power of female music with the idea of a musical harmony that governed the heavens, the political world, and the human soul to legitimize female power. By blending the talents of Elizabeth's natural body with those of her political body, and by merging practical musicianship with speculative harmony, Elizabeth and her courtiers used music as a source of political authority.
\end{abstract}

\section{INTRODUCTION}

$\mathrm{Q}$ ueen Elizabeth I (r. 1558-1603) had a reputation as a musical monarch. She played the virginals, the lute, and similar plucked string instruments; she sang, danced, and on one occasion claimed to have composed dance music. ${ }^{1}$ Yet while a musical education was typical for women of royal and noble birth, Elizabeth's unusual position as a ruling queen allowed her music-making to develop a political role as part of her royal image. ${ }^{2}$ Initially, praise of Elizabeth's musicality closely paralleled that given to other women, focusing on her practical talents and role as a patron, and evoking the sensual attractiveness typically associated with female

"I wish to thank my supervisor, Dr. Stephen Rose, for his guidance during my $\mathrm{PhD}$ research and in preparing this article. I am also grateful to the Arts and Humanities Research Council for providing my funding. This article is related to chapter 2 of my thesis, "Image and Influence: The Political Uses of Music at the Court of Elizabeth I" (University of London, 2011).

${ }^{1}$ Melville, 95-96; Maisse, 95; Klarwill, 228, 96; Württemberg and Frederick, 12; Clapham, 89. For musicians of the Royal Household, see Holman, 104-22; Ashbee and Lasocki, 2:1189-1211; Lasocki, 143-93.

${ }^{2}$ For studies of other English female musicians in the sixteenth and early seventeenth centuries, see Pollack, 399-424; Austern, 2008, 135-38, 141-46. 
performers. However, in the 1580s and 1590s Elizabeth's poets and courtiers drew on musical images of political harmony to associate her musicality with power and authority, asserting her suitability to rule.

Elizabeth had a continuing need to defend her monarchical abilities against misogynist critics. Attitudes toward Elizabeth's female rule ranged from John Knox (ca. 1514-72) condemning all women in The First Blast of the Trumpet Against the Monstruous Regiment of Women (1559) as "weake, fraile, impacient, feble and foolish ... vnconstant, variable, cruell and lacking the spirit of counsel and regiment," to Robert Cecil (1563-1612) remarking in a letter in the months after her death that she was "more than a man, and (in troth) sometyme less than a woman." " Recent historians have recognized that Elizabeth exploited traditional gender stereotypes like those recited by Knox, but have also insisted, like Cecil, on her exceptional nature. Carole Levin has presented Elizabeth as able to "capitalize on the expectations of her behavior as a woman and to use them to her advantage," and also to "plac[e] herself beyond gender expectations by calling herself king." ${ }^{4}$ Similarly, Louis Montrose has argued that representations of Elizabeth both politicized traditional images of womanhood and eroticized the political sphere through the rhetoric of courtly love that characterized her relationships with her courtiers. ${ }^{5}$ To assert her authority she drew on female stereotypes but insisted that she was an exceptional woman.

Elizabeth's musical image also exploited and subverted gender stereotypes to justify her political authority. Significantly, music was capable of evoking both feminine and masculine qualities. On the one hand, music was considered sensual, feminine, and frivolous. Music and feminine beauty alike were jointly regarded as able either to incite amorous passions or to inspire contemplation of heaven, while music was also accused of emasculating young men. ${ }^{6}$ Conversely, music could evoke masculine attributes of rationality and order through its traditional basis as a mathematical art and through the belief that musical harmony governed the heavens, the political world, and the human soul. ${ }^{7}$ Music was therefore a means to reconcile Elizabeth's female sex with her gendered masculine position of political authority.

\footnotetext{
${ }^{3}$ Knox, 10; Harington, 1:345 (letter to Sir John Harington, 26 May 1603).

${ }^{4}$ Levin, 1994, 1.

${ }^{5}$ Montrose, 1983.

${ }^{6}$ Austern, 1989; Austern, 1993.

${ }^{7}$ Hollander, 20-51; Wells, 4-7.
} 


\section{Sensuality and Rationality: The Connotations OF MUSIC FOR QUEENS}

Music was one of the talents expected of well-educated and broadly accomplished young women of royal and noble birth. They were to become the eloquent, attractive centerpieces of Renaissance courts, with a duty to charm and entertain foreign visitors. Richard Mulcaster (1531/ 32-1611), Headmaster of the Merchant Taylors' School, argued in 1581 that princesses especially needed the talents of "reading well, writing faire, singing sweete, playing fine" in order to "honour themselues, and to discharge the duetie, which the countries committed to their hands, do daily call for, and besides what match is more honorable, then when desert for rare qualities, doth ioine it selfe, with highenesse in degree?"8 One of these duties, described by Lord Julian in Castiglione's The Courtyer (translated into English by Thomas Hoby in 1561), was to "entertein accordingly both with Iestes \& feat conceites meete for her, euerie person that commeth in her company." Singing or playing on the lute or virginals could provide such entertainment, although she was to do so in private gatherings and with modesty; she should be "brought to it $\mathrm{w}^{\mathrm{c}}$ suffringe her self somewhat to be prayed and with a certein bashfulnes, that may declare . . . noble shamefastnes," and avoid "those harde and often diuisions that declare more counninge then sweetenesse." 10

A princess's musical education was intended not only to make her a performer but also to prepare her for a role as a patroness of musicians, by giving her the knowledge by which to judge the performances of others. Dietrich Helms has argued that "Henry VIII's Book" (now in the British Library, Add MS 31933) — a selection of well-known Continental songs, pieces from court festivals, and compositions by Henry VIII (1491-1547) was prepared to instruct the royal children in forms of secular music. ${ }^{11}$ By studying such models they could gain what Castiglione termed the "knowleage to praise and make of Gentilmen more and lesse accordinge to their desertes" in the context of a musical performance. ${ }^{12}$ The high reputation such courtly women might gain through their musical talent and patronage is demonstrated by Isabelle d'Este, Marchioness of Mantua (1474-1539), who may have been a model for Castiglione's ideas of the

${ }^{8}$ Mulcaster, $180-81$.

${ }^{9}$ Castiglione, $\mathrm{Cc} 2^{\mathrm{r}}$.

${ }^{10} \mathrm{Ibid}$., $\mathrm{Cc1}^{\mathrm{v}}$. "Diuisions" refers to a type of ornamentation where the melody is divided into notes of smaller values.

${ }^{11}$ Helms.

${ }^{12}$ Castiglione, $\mathrm{Ccl}^{\mathrm{v}}$. 
conduct of gentlewomen. ${ }^{13}$ Isabella used her exceptional musicality to earn herself a fame usually only achievable by men, being renowned as a performer, setting the direction of musical culture at the Mantuan court, and aiding in the development of a new genre, the frottola. ${ }^{14}$

A courtly woman's use of music to demonstrate her good breeding, to judge the performances of others, and to perform in noble company when called upon differs little from the benefits of music to a male courtier. ${ }^{15}$ However, music was also frequently presented as a means through which women could attract a suitable husband. Mulcaster writes that "the young maidens being well trained are verie soone commended to right honorable matches, whom they may well beseeme, and aunswere much better, their qualities in state hauing good correspondence, with their matches of state, and their wisedoms also putting to helping hand, for the procuring of their common good." 16 Yet although Mulcaster uses a gender-neutral notion of "common good" to justify music's advantages for young women, it was not only music's status as a social accomplishment that made it useful in attracting a husband, but also its sensual connotations. Robert Burton offered a more realistic view in his 1621 analysis of love melancholy, where he concluded that music was "the way their parents thinke to get them husbands" because "tis a great allurement as it is often vsed, and many are vndone by it." Music was a tool of courtship with which a young woman might make herself desirable to a young gentleman because "to heare a faire young gentlewoman to play vpon the Virginalls, Lute, Viall, and sing to it, must needs be a great entisement." ${ }^{, 17}$

The combination of music and beauty was invariably equated with female attractiveness. This relationship is captured in an epigram describing the performance of a noblewoman by Sir John Harington (1560-1612), "In praise of my Lady R: and her musick":

Vpon an instrument of pleasant sounde a lady playd more pleasing to the sight

I being askt in which of theis I found greatest content, my sences to delight Ravisht in both at once as much as may be said sweet was Musick, sweeter was the Lady. ${ }^{18}$

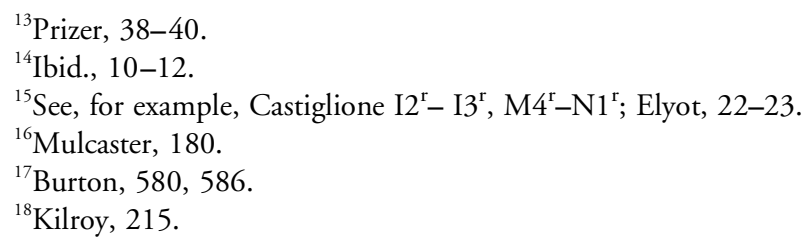


The poem offers a stereotypical situation in which a man is captivated by an attractive woman's eloquent and beautiful music. Music represents an intimate bond between the lady and the male listener, and at its most positive the love inspired by the music of women might even be likened to that of angel musicians, stirring the listener to thoughts of heaven. ${ }^{19}$

Yet female musicians were frequently accused of inciting lust, and compared with courtesans and the Homeric Sirens in their threat to male self-control. ${ }^{20}$ The lute in particular was a visual symbol for sex in Renaissance portraiture, due to its use by Venetian courtesans as the badge of their trade. Both Julia Craig-McFeely and Carla Zecher agree that the iconography of a lute-playing woman invited erotic interpretations. ${ }^{21}$ This association of music with sinful pleasures was representative of arguments over music's position as virtue or vice that had been raging since the 1470s. Rob Wegman has described how controversy over the use of polyphony in churches (as opposed to plainchant) set the terms for sixteenth-century debates over music's sensuality or rationality, moderation or excess, and sin or virtue. ${ }^{22}$ These ideas were applicable to the music of both genders: the roles could be reversed, with men depicted serenading women, and the lute could be likened to both male and female sexual organs in poetry. Yet it was female performers who were most readily assumed to be lustful and licentious. ${ }^{23}$ This inherent sensuality of music meant that female musicians had to be cautious about the contexts and company in which they performed.

Such criticisms of women performing music are found in the book written for the education of Mary I (r. 1553-58) at the request of Catherine of Aragon (1485-1536), and later used for Elizabeth: Juan Luis Vives's (1492/93-1540) The Instruction of a Christian Woman (1524, translated into English in 1529 with numerous subsequent editions until 1592). ${ }^{24}$ Vives argued that he did not want a woman "idle as were the Women of Perseland, drowned in voluptuousnesse and pleasures, sitting among the company of gelded men, singing and banketting continually." ${ }^{25}$ Here music is represented as part of the orientalized Other of Persia, where sensual pleasures such as music and indulgent feasting emasculated young men so that they became eunuchs. The problem with Vives's advice was that these

\footnotetext{
${ }^{19}$ Austern, 1989, 421-23; Calogero, 140-46.

${ }^{20}$ Austern, 1989, 424, 427, 431-34; Calogero, 140-41, 146-56; Zecher, 772-74.

${ }^{21}$ Zecher, 772, 774; Craig-McFeely, 300-01, 312.

${ }^{22}$ Wegman, 179.

${ }^{23}$ Craig-McFeely, 300-01, 310-12; Zecher, 769-91.

${ }^{24}$ Fantazzi.

${ }^{25}$ Vives, 10
} 
were just the kind of activities that did take place at court. Elizabeth's court would be no exception, with plays, banquets, masques, and tournaments celebrating events like Christmas, Shrovetide, Accession Day, and her royal progresses. ${ }^{26}$

Furthermore, Vives considered women particularly susceptible to sensuous pleasures such as music, which was associated with unchaste behavior: "Loue is breade by reason of company and communication with men: for among pleasures, feastes, laughing, daunsing, and volupties, is the kingdome of Venus and Cupide. And with these things folkes mindes be entised and snared, and specially the womens, on whome pleasure hath sorest dominion." 27 Castiglione's character, Count Lewis, concurs that a woman's "tender and soft breastes are soone perced with melody and fylled with swetenesse." ${ }^{\prime 2}$ However, Vives's criticism of women's susceptibility to pleasure contrasts with the positive assessment of the role of women as the inspiration for male music-making in Castiglione's The Courtyer: as Lord Cesar asks, "Who learneth to daunce featlye for other, but to please women? Who applyeth the sweetenesse of musicke for other cause, but for this?"29 Such divergences between courtly conduct books demonstrate how important it was for women to foster the right kind of musical image, presenting themselves as attractive and respectable, rather than wanton and unchaste.

The perceived power of women's music to undermine male rationality and authority also caused particular concern. In Harington's epigram, the delight in a lady's music remains non-threatening. Although "ravisht," the male listener maintains his position of authority and his rational thought as he acts as judge and observer of the sweetness of the music and the lady. However, A Mirrhor Mete of all Mothers, Matrones, and Maidens (1579) by Thomas Salter (fl. 1579-81) uses the myth of the Sirens as a warning: "from the false sweetenesse of the Sirens songes, Ulisses a Prince famous emong the Grekes, and saied to be nourished with heauenly foode, in the verie bosome of Sapiencs Iupiters doughter, could hardly escape, and shall wee then without feare, giue so muche trust to a young Maiden, daintely and tenderly trained vp, that she not onely by hearyng, but by learnyng so wanton an Arte, will not become wanton and effeminate." 30 "'Sapiencs Iupiters doughter" is

\footnotetext{
${ }^{26}$ For example, see Chambers (especially volume 4) for plays and masques at court; Nichols, for accounts of progresses; Young, for tournaments.

${ }^{27}$ Vives, 137.

${ }^{28}$ Castiglione, $\mathrm{I} 2{ }^{\mathrm{r}}$.

${ }^{29}$ Ibid., Ii1 ${ }^{\mathrm{v}}$.

${ }^{30}$ Salter, $C 7^{\mathrm{r}}$.
} 
Athena, Goddess of Wisdom, Ulysses's protector.) Music was not just dangerous for the young woman herself, but hazardous for the young men who heard her.

Yet the same myth of the Sirens was used as a positive example of female musical talent in A Womans Woorth, Defended Against all the Men in the World (a 1599 English translation of Alexandre de Pontaymeri's Paradoxe Apologétique, où il est fidellement démonstré que la femme est beaucoup plus parfaite que l'homme en toute action de vertu of 1594): "The Syrens . . . had songs so wonderfull sweete and mellodious: as they could outeare the windes, and rob all mouthes of their naturall offices. The Greekes returning from the warres of Troye, rested themselues a long while in those Isles . . . little caring for returne home to their owne country, by being rapt, or rather charmed by such an hermonious delight." ${ }^{31}$ In this retelling of the Sirens' story, music gives women the power to control not only men, but also mythological heroes, and even the winds. Furthermore, the traditional gender hierarchy was inverted by acknowledging music as a skill in which "the glory which women have gotten thereby [is] ouer-far beyond men." In defenses of music such as this one, we see the flexibility of music's gendered connotations and how mythological stories could be manipulated to create different representations of musical women. Such images of female power might be usefully appropriated by a ruling queen.

The volatile meanings associated with musical women may be one reason why Elizabeth and her courtiers sought to control her musical image. Many of the associations between music and femininity were incongruous with Elizabeth's image as the chaste virgin queen. Queens were not immune from men casting aspersions on their morality by making allegations of amoral behavior caused by music. The privileged access that musicians had to private chambers as performers and tutors led to accusations of sexual liaisons between princesses and male musicians. Elizabeth's own mother, Anne Boleyn (ca. 1500-36), was accused of having an affair with musician Mark Smeaton. He pleaded guilty to "violation and carnal knowledge of the Queen" and was executed in 1536 along with the courtiers Sir Henry Norris, Sir William Bryerton, and Sir Francis Weston, as well as Anne herself. ${ }^{32}$ The investigations into the infidelity of Katherine Howard (ca. 1520-42), another of Henry VIII's wives, included an account of misconduct three or four years previously with a player of the virginals called Henry Monoxe, with details of them exchanging love tokens, holding unchaperoned

\footnotetext{
${ }^{31}$ Pontaymeri, $24^{\mathrm{r}}, 26^{\mathrm{v}}$.

${ }^{32}$ Brewer, Brodie, and Gairdner, 10:351-52 ("Trial of Weston, Norris and Others," 12 May 1536).
} 
meetings, and Monoxe's claim that Katherine had promised him her maidenhead. ${ }^{33}$ The close relationship between Elizabeth's cousin Mary Stuart (Mary Queen of Scots, 1542-87) and David Rizzio (ca. 1533-66), who was first employed as a singer but later became her Secretary for French Affairs, was also criticized. In his historical memoirs, Lord Herries wrote of the rumors that were spread around the Scottish court: "Tales were sometimes minced out, as though David Rizius was many tymes too intimatt with the Queen, more than was fitting," and "it was openlie said that she tooke more pleasure in his companie than in the King's, her husband's; that she made him sitt at her table with her, and had free access to her bedchamber, at all hours." Lord Herries was skeptical of the validity of these claims but recorded that they were nevertheless "cryed out with open mouth, to diffaim her and incense her husband." 34 "This criticism largely reflected the nobility's jealousy over the power given to a foreigner of such low birth, but it led to Rizzio's murder by members of the nobility, including Mary's husband, Lord Darnley.

Despite the risk of such allegations, it was normal for a queen to have musicians, particularly singers and keyboard players, among her Privy Chamber staff to give private performances for her entertainment. Elizabeth too had male musicians on the staff of her Privy Chamber, such as the composer Alfonso Ferrabosco (the Elder), the lutenist Mathias Mason, and the virginal player Ferdinand Heyborne/Richardson, and she also took particular pleasure in the singing of Robert Hales. ${ }^{35}$ No such rumors of affairs with musicians are known concerning Elizabeth. Yet the previous examples show how a queen's association with musicians could easily be seen as a sign of her immorality if her reputation became damaged, or if she simply became unpopular. Not only did the intimate settings of the performances of Privy Chamber musicians provide the opportunity for rumors to be spread, but the association of music with lust and prostitutes made such accusations all the more convincing for the music-loving lady.

Elizabeth never seems to have become unpopular enough for her musicality to become a source of allegations of immorality, but she was not entirely immune to criticisms of her love of music and dancing. Aside from the sensuality of music, delighting in song and dance might also be seen as a sign of foolishness and lack of education. Vives wrote that "the minde, set uppon learning and wisdome . . . shall leaue all such light and trifling

${ }^{33}$ Fitzwilliam, $110^{\mathrm{r}}-111^{\mathrm{v}}$.

${ }^{34}$ Herries, 69, 75.

${ }^{35}$ Ashbee and Lasocki, 1:407-09, 532-33, 565-66, 2:779, 1189-91; Holman, 38; Poulton, 1957. 
pleasures, wherein the light fantasies of maydes haue delight, as songes, daunces, and such other wanton and peeuish playes. A woman sayeth Plutarch, giuen unto learning, will neuer delight in dansing." 36 Therefore a musical reputation might reinforce stereotypes of weak, foolish womankind and prevent Elizabeth from establishing an image as a wise and capable monarch. In 1563, Francis Challoner criticized the court's inactivity (writing this critical comment in Latin in a letter otherwise in English): "The Queen is entirely given over to love, hunting, hawking, and dancing; consuming day and night with trifles; nothing is treated earnestly; and though all things go wrong they jest, and he who invents most ways of wasting time is regarded as one worthy of honour." ${ }^{37}$

Disapproval also seems to be implied by Lodowick Lloyd, one of her sergeant-at-arms, who wrote in The Pilgrimage of Princes (1573) "thus was the auncient musicke in the beginning so necessary, that euery countrey endeuoured to haue skyll in musicke: then Mars claimed musicke in the feelde, nowe Venus occupieth musicke in Chaumbers, that kinde of gentle and softe musicke the Egyptians forbad the youth to bée taught therein, lest from men they woulde become againe women." ${ }^{38}$ Given Lloyd's court position, it is likely that his disapproval of feminine, sensual music was intended as a mild criticism of the atmosphere in the court of the queen: this was necessarily less warlike because, as a woman, Elizabeth could not participate directly in military affairs. These criticisms of the jollity or sensuality of Elizabeth's court belong only to the first fifteen years of her reign, suggesting that they reflect the skepticism of courtiers and ambassadors of a woman's suitability to rule, more than any real flaw in Elizabeth's style of court. Yet when considered alongside contemporary scandalous rumors — such as her having a child with Robert Dudley — the potential for a very different image of an immoral and licentious queen is evident. ${ }^{39}$ Later in this article we shall see that Elizabeth and her court poets carefully constructed her royal image to ensure that her music-making remained associated with eloquence, prosperity, and chaste, youthful beauty.

${ }^{36}$ Vives, 27

${ }^{37}$ Stevenson, 6:624; Challoner, 94v: "Regina tota amoribus dedita est venationis accupiis choreis $\&$ rebus ludicris insumus dies noctesque, nihil serio tractatur, quanque omnia adverse cedant tamen iocamur hic perinde ac si orbem vniversum debellati fuerimus \& qui plures vere nugandi modos ridiculo studio excogitauerit (quasi vir summio premio dignus) suspicitum."

${ }^{38}$ Lloyd, $115^{\mathrm{r}}$.

${ }^{39}$ Fox, 362. 
Aside from connotations of sensuality, a well-established intellectual tradition associated music with authority, rationality, and order, inspired by music's status as a mathematical art and a belief in a universal harmony, all of which Elizabeth deployed to project her image as a ruler. Elizabethan beliefs in musical harmony were inherited from classical authors such as Plato, Aristotle, and Cicero, and particularly from Boethius's transmission of classical ideas in his De Institutione Musica (written in the early sixth century, but still read as an authority on music in the sixteenth century). Boethius identified three different types of musical harmony: musica mundana (universal music), musica humana (human music), and musica instrumentalis (instrumental music). ${ }^{40}$ Musica mundana was the heavenly harmony produced by the movements of the planetary spheres. Each sphere was believed to produce a sound, all of which together formed the celestial harmony. The sound was believed to be produced either by the supposedly glassy spheres rubbing against each other (as related in Cicero's Somnium Scipionis), or by a singing female muse or siren that governed each sphere (as in book 10 of Plato's Republic). ${ }^{41}$ These muses or sirens became angels as the myth was adapted to Christian imagery of the heavenly choir. ${ }^{42}$ Musica humana was the harmony of the human soul, and between the soul and the body, while musica instrumentalis was the audible music of everyday life produced by instruments and voices.

These celestial, human, and instrumental harmonies were seen as interconnected. Musicians could aspire to alter the passions of the human soul or even to command animals, plants, and rocks if they succeeded in imitating the music of the heavens, as in the myths of Orpheus, Arion, and Amphion. ${ }^{43}$ Similarly, the anonymous treatise The Praise of Musicke (1586) described how the soul's memory of celestial harmony made it susceptible to the influence of audible music, and suggested that music's ability to connect heaven and earth gave it a religious and moral purpose. ${ }^{44}$

Plato's view in book 3 of The Republic that political communities could be kept peaceful and ordered through control of the music also found echoes in the Elizabethan concept, extending those set out by Boethius, of the political harmony of the commonwealth. The idea can be seen in Shakespeare's Henry $V(1599)$, when the Duke of Exeter uses the metaphor of government as "high and low and lower" parts that, once set, continue "Congreeing in a full and

\footnotetext{
${ }^{40}$ Treitler, $140-41$.

${ }^{41}$ Plato, 340; Hollander, 29-30.

${ }^{42}$ Hollander, 29.

${ }^{43}$ Ibid., 14, 162-76; Wells, 4-7.

${ }^{44}$ The Praise of Musicke, 40-42.
} 
natural close / like music" to argue that the King may go to war with France in the knowledge that his kingdom will be secure in his absence. ${ }^{45}$ The hierarchical ordering of the estates was conceived as mirroring the orbits of the spheres arranged from low to high tones. Political harmony is famously compared to that of both the planets and instrumental music in Ulysses's speech on degree in Shakespeare's Troilus and Cressida (1601-02), where Ulysses suggests that lack of respect for degree and hierarchy is to blame for the Greeks' failure to defeat Troy. ${ }^{46}$ Although Ulysses's speech illustrates a commonplace view of music and social order, literary critics such as Una Ellis-Fermor, Anthony Dawson, and Gwynne Blakemore Evans have noted that this image is undermined both by Ulysses's failure to follow his own ideals, and by the conclusion of the play, in which discord and chaos reign (for example, in the ambush and murder of Hector). ${ }^{47}$ This potential for images of harmony to be transformed into their opposite for purposes of critique will also be seen in the portrayals of Elizabeth's rule in the later years of her reign.

This notion of harmony was not simply metaphorical: in his The Boke Named the Gouernour (1537), Sir Thomas Elyot (ca. 1490-1546) justified the place of music in the education of gentleman being prepared for public life as "necessary ... for the better attaining the knowlege of a publyke weale, which ... is made of an ordre of astates and degrees, and by reason therof conteyneth in it a perfect harmony." 48 This would make little sense as practical advice unless there was widespread belief in these interconnected levels of harmony. Despite the latent alternative metaphors of discord, it was such connotations of rationality and governance that made music most useful to Elizabeth's monarchical image, and that distinguished her portrayals as a musician from those of other women.

\section{Music in The Royal Image}

Elizabeth's use of her own musical performances for political purposes relied on music's sensuality and intimacy. Performances usually took place in her private rooms. In 1564 the Scottish ambassador, Sir James Melville (1535/ 6-1617), was taken by Lord Hunsdon to a "quiet gallery" and a chamber where Elizabeth was alone and playing the virginals. Adam Zwetkovich, ambassador to Emperor Maximilian II (r. 1527-76), heard Elizabeth dance

\footnotetext{
${ }^{45}$ Shakespeare, 1997, 1461 (Henry V, 1.3.180-83).

${ }^{46}$ Ibid., 1847 (Troilus and Cressida, 1.3.85-111).

${ }^{47}$ Evans, 431; Shakespeare, 2003, 43-46; Ellis-Fermor, 69-74.

${ }^{48}$ Elyot, $22^{\mathrm{r}}$.
} 
and play on the lute and clavichord in "her apartments" in $1565 .{ }^{49}$ Even outside her private quarters, Elizabeth's performances created a sense of privileged intimacy with the queen. The previous Imperial Ambassador, Baron Breuner, in 1559 reported how he "took a boat on the river, and the Queen came there too, recognized and summoned me. She spoke a long while with me, and invited me to leave my boat and take a seat in that of the Treasurer's. She then had her boat laid alongside and played upon the lute. ${ }^{" 50}$ Performing on the lute was itself a means to fashion private space. Lute performances were not public spectacles, but took place in private contexts, while the lyrics of lute songs were introspective and often enacted seemingly personal confessions, especially of melancholy or love. ${ }^{51}$ While ambassadors would be keen to emphasize their closeness to the queen in their reports, her choice of place and instrument nevertheless suggests that Elizabeth used musical performance to give ambassadors the illusion that they were being drawn into her circle of intimates. Furthermore, the 1559 and 1565 performances took place during diplomatic negotiations concerning potential suitors for Elizabeth, and we have seen how music, and in particular the lute, was associated with marriage and female attractiveness. ${ }^{52}$ In such a context, these ambassadors could hardly fail to interpret these performances as a demonstration of her desireability.

Those who heard Elizabeth's performances frequently evoked the image of the sensuous, enchanting musician in their accounts. Melville drew on this trope to excuse his eavesdropping on the queen's virginal playing (Elizabeth having caught him standing in the door of her chamber), declaring that he "heard such melody as ravished me, whereby I was drawn in ere I knew how." ${ }^{\text {53 }}$ Although Melville was employing flattery to get himself out of a tricky situation, his account resonates with the stereotypes of seductive female performers, among which Elizabeth's playing might be understood. His comments were echoed many years later in a letter of Don Virginio, the Duke of Orsino, to his wife in 1601. The French ambassador, Monsieur de Boissise, reported that Elizabeth "danced, played and sang for love of him [Orsino]. ${ }^{\prime 54}$ Orsino's accounts are vague (he tells his wife he is saving the details until his return), but following a meeting in which Elizabeth had specifically promised to perform, he wrote "it seemed to me

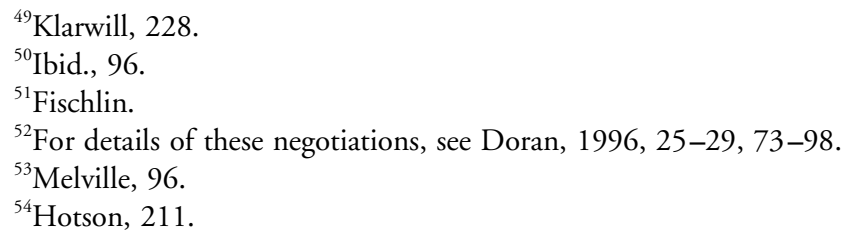


I had become one of the paladins who used to go to those enchanted palaces." ${ }^{" 5}$ Orsino employed the same connotations of exotic otherness displayed in Vives's Instruction of a Christian Woman: however, for Orsino this was a sign of the captivating sumptuousness of Elizabeth and her court, rather than a cause for condemnation. Such sensuality was an aspect of Elizabeth's governance that Sir Francis Bacon (somewhat reluctantly) admitted to have been effective. He wrote in his memorial In Felicem Memoriam Elizabethae (1606) that "she allowed herself to be wooed and courted and even to have love made to her ... much like the accounts we find in romances of the Queen in the blessed islands ... who allows of amorous admiration but prohibits desire. . . . Certain it is that these dalliances detracted but little from her fame and nothing from her majesty and neither weakened her power nor sensibly hindered her business." ${ }^{" 56}$ Orsino's and Bacon's accounts related Elizabeth and her court to the world of chivalric romances. Her music-making helped Elizabeth to create the impression of her court as an alluring, intimate fantasy world in which she, as the unattainable beloved, was the central focus of admiration and devotion. This atmosphere of courtly love allowed Elizabeth to appropriate the traditional erotic and musical powers that women were said to have over men in order to assert her primacy in courtly and diplomatic relationships. ${ }^{57}$

As music was associated particularly with young, unmarried women, it also had a role in maintaining Elizabeth's illusion of eternal youth as she aged. ${ }^{58}$ Elizabeth continued her performances into old age. In 1589 John Stanhope of the Privy Chamber reported that "the Q. is so well as I assure yow VI or VII gallyards in a mornynge besydes musycke \& syngyng, is her ordynary exercyse," while in 1592 she performed on an instrument with gold and silver strings for the visiting Frederick Duke von Württemberg. ${ }^{59} \mathrm{~A}$ letter from a Londoner, John Chamberlain, to Dudley Carleton (a young gentleman who was traveling abroad and seeking a diplomatic appointment) reporting rumors from the court about the queen's entertaining of Don Virginio (1601) shows a similar interpretation of her dancing: "The Queen entertained him very graciously, and to shew that she is not so old as some wold have her, daunced both measures and galliards in his presence. ${ }^{\prime 60}$ Yet

${ }^{55}$ Ibid., 210.

${ }^{56}$ Bacon, 1857-74, 11:460.

${ }^{57}$ Elizabeth's use of games of courtship as a political tool is also commented on in Bates, 45-88; Montrose, 1983, 83-85.

${ }^{58}$ Montrose, 2006, 211-28; Strong, 1977, 47-54; Strong, 1983, 118-21.

${ }^{59}$ Poulton, 1982, 405. Württemberg and Frederick, 12.

${ }^{60}$ Hotson, 211-12. 
Castiglione's criticism of old men who performed music in public must surely have been equally applicable to old women: "it were ... an yll sight to see a man of eny estimation being olde, horeheaded and toothlesse, full of wrinckles with a lute in his armes playing vpon it $\&$ singing in the middes of a company of women ... suche songes conteine in them woordes of loue, and in olde men loue is a thing to bee iested at. ${ }^{\prime 61}$ Indeed, Nanette Salomon has argued that there was no appropriate positive image of aging women that Elizabeth could employ. Portraits of mature men communicated experience, wisdom, and power, while those of aging women were positive only when showing a mother with her children. Otherwise, old women were associated with sin, vice, decay, and even witchcraft, as opposed to the virtuous Virgin Mary, who was depicted as young. ${ }^{62}$ The atmosphere of love and attraction that Bacon suggested was an important aspect of Elizabeth's style of government, relied on her remaining desirable. The reality of aging had to be disguised by pretence, and Elizabeth's music-making played a part in this.

However, images of Elizabeth in her role as musical patroness moved away from the purely sensual, with its implications of frivolity and wantonness, and developed music's potential connotations of intelligence, refinement, rationality, and harmony of mind. When court musicians William Byrd (ca. 1540-1623) and Thomas Tallis (ca. 1505-85) dedicated their 1575 Cantiones Sacrae to Elizabeth, they praised "the refinement of [her] voice or the nimbleness of [her] fingers," but they also claimed that her practical skill made her able to judge their work. ${ }^{63}$ Recalling Helm's argument about the role of royal men and women as judges of musical quality, we see that Tallis and Byrd presented Elizabeth as matching such expectations. Furthermore, musical judgment was more highly esteemed than practical skill in music because it involved reason and intellect. In his De Institutione Musica, Boethius distinguished performers (with physical skill but little understanding of music) and composers (who compose song by natural instinct) from those with the ability to judge music, of whom he wrote: "This class is rightly reckoned as musical because it relies entirely upon reason and speculation. And that person is a musician who possesses the faculty of judging." ${ }^{64}$ Tallis and Byrd therefore associated Elizabeth with the highest form of musicianship, where music is no longer merely sensual but responded to rationally and intellectually. The image of Elizabeth as an intelligent and eloquent patroness was also employed by poets who

\footnotetext{
${ }^{61}$ Castiglione, $\mathrm{M} 4{ }^{\mathrm{v}}$.

${ }^{62}$ Salomon, 82-83.

${ }^{63}$ Byrd, xvii, xxv: "qua . . . es peritia"; "vel vocis elegantia, vel digitorum agilitate facile."

${ }^{64}$ Treitler, 142.
} 
presented her as best of the Muses. Poet Michael Drayton (1563-1631) described Elizabeth as "Queene of Muses" in the shepherds' tributes to the nymph "Beta" in Idea the Shepheards Garland (1593), while schoolmaster Richard Mulcaster took care to emphasize her virtue as well as her eloquence, writing in 1581 that, "it is for our most worthy Princesse, to haue the presidencie ouer nyne men, the paragons of vertue: and yet to be so familiarly acquainted with the nyne muses, as they are in strife who may loue her best, for being best learned."

Elizabeth's image as a musical patroness able to give reasoned judgment allowed her musicality to become associated with the speculative harmony of the spheres. The consort song "Elisa Her Name Gives Honor" by John Bennet (fl. 1599-1614), ends with the conceit that earthly music is not good enough for her ears:

I sing adoring

humbly imploring

That my rude voice may please her sacred ears,

Whose skill deserves the music of the spheres. ${ }^{66}$

This song connects two different types of music: the audible music of the singer and consort performing the song, and the inaudible harmony of the celestial spheres. While the skill of Elizabeth's ears indicates primarily her talents as performer and patroness, the music of the spheres could evoke the harmony of the mind and soul. Sir John Davies (ca. 1569-1626), poet and servant-in-ordinary to Elizabeth, developed these connotations of rationality and mental concord in his poetic Hymnes to Astraea (1599). In the poem "Of the Organs of her Minde" (an acrostic of Elizabeth's name) he wrote:

By Instruments her powers appeare

Exceedingly well tun'd and cleare:

This Lute is still in measure,

Holds still in tune, euen like a spheare,

And yeelds the world sweet pleasure. ${ }^{67}$

Elizabeth's mind is compared both to earthly instruments and to heavenly spheres. Connecting the practical and speculative aspects of music, the reference to lutes and instruments evokes Elizabeth's own lute-playing and the musical ensembles of her court. Although "her powers" refers to the powers of Elizabeth's mind, the choice of word recalls the authority of

\footnotetext{
${ }^{65}$ Drayton, 16; Mulcaster, 173-74.

${ }^{66}$ Bennet, $9^{\mathrm{v}}\left(17790,5^{\mathrm{v}}-6^{\mathrm{r}}\right)$.

${ }^{67}$ Davies, 1599, 19.
} 
a queen, while the emphasis on the repeated word "still" evokes Elizabeth's motto, semper eadem ("always the same") and stresses her constancy. Constancy was not a quality typically associated with women: the French ambassador reported a complaint by the Earl of Essex in 1597 that, "they laboured under two things at this court, delay and inconstancy, which proceeded chiefly from the sex of the Queen." ${ }^{\text {"68 }}$ Although, like Byrd and Tallis, Davies was concerned with portraying Elizabeth's intellectual virtues rather than her feminine attractiveness, the description of these virtues bringing "sweet pleasure" nevertheless continues to evoke conventional portrayals of the sensual delights of women's musical performances.

This imagery was not unique to Elizabeth but was also applied to other female patrons. John Dowland praised the "well tuned . . . minde" of his dedicatee, Lady Lucy Russell, Countess of Bedford (ca. 1581-1627), in his Second Booke of Songs or Ayres (1600), in which the dedicatory poem (an acrostic) also added connotations of piety:

By this thy tunes may haue accesse,

Euen to hir spirit whose flowring treasure,

Doth sweetest Harmonie expresse,

Filling all eares and hearts with pleasure

On earth, obseruing heauenly measure. ${ }^{69}$

It is not only Lucy's mind, but also her soul, that has harmony, and this harmony is divine. The sweetness of her music and the pleasure it gives to "ears and hearts" evoke a sensual realm, yet also inspire spiritual devotion.

However, whereas such images of harmonious women usually extended only to their personal virtues, Elizabeth's musicality became a representation of her power, her position as divinely-appointed monarch, and her Godgiven abilities to rise above the weaknesses stereotypically presumed of her sex. Poets such as Edmund Spenser, Sir John Davies, and Thomas Churchyard portrayed Elizabeth not only as musician, patroness, and pious woman, but also as the bringer of divine harmony to earth and the creator of political harmony in her kingdom.

\section{MUSIC AND GOVERNANCE}

The earliest identification of Elizabeth with political harmony refers not to the music of the spheres, but to the myth of Pan and Syrinx: however, it evokes the same connotations of harmony, order, and even divinity. Edmund

${ }^{68}$ Maisse, 115 .

${ }^{69}$ Dowland, A2 ${ }^{\mathrm{r}}, \mathrm{A} 3^{\mathrm{v}}$. 
Spenser (1552?-99) created a mythic reinterpretation of Elizabeth's birth that emphasized her harmonious persona in the "Aprill" eclogue from The Shepheardes Calender (1579): "For she is Syrinx daughter without spotte I Which Pan the shepheards God of her begot." ${ }^{70}$ In the myth, Syrinx was fleeing the seductions of Pan when she was turned into reeds to preserve her chastity. Pan then cut the reeds and turned them into his pipe. The commentary that accompanied Spenser's Shepheardes Calender on its first publication explained how Pan was Henry VIII, a fitting persona given Pan's position as God of the Shepherds. ${ }^{71}$ This reinterpretation of Elizabeth's birth was necessary because Elizabeth's mother, Anne Boleyn, had been beheaded for adultery, and Elizabeth declared a bastard. Many Catholics did not accept the legitimacy of Henry's annulment of his marriage to Catherine of Aragon, which had allowed his union with Anne, and in 1570 a Papal Bull of Excommunication had also declared Elizabeth illegitimate. ${ }^{72}$ Spenser was creating a divine parentage and an immaculate conception for the Virgin Queen to compensate for her uncertain legitimacy. However, a further layer of interpretation is suggested by the fact that in this metaphorical representation of her birth, as Philippa Berry has pointed out, Elizabeth is the song from Pan's pipe. ${ }^{73}$ We have already seen that music was closely related to social and political harmony. As well as being god of Shepherds, Pan was also connected with disorder, lust, and chaos, associations that might have been considered equally applicable to Henry by those who recalled the disruptions of the Reformation and Henry's numerous wives. Therefore, this mythical birth that Spenser invented not only emphasized the legitimacy of Elizabeth's birth (and therefore her rule), but also created a narrative by which Elizabeth was the peaceful concord born out of the disorder of Henry's reign. Elizabeth was represented as music personified, destined to bring about the peace and order of the Golden Age.

Images of Elizabeth embodying a musical harmony that transformed chaos into a peaceful, ordered paradise were enacted in a series of tableaux staged on Elizabeth's visit to Bisham during her summer progress in 1592. The host, Lady Elizabeth Russell (1528-1609), commissioned the tableaux which greeted Elizabeth as she traveled along the road leading to the house. At each, characters underwent a metamorphosis in the queen's presence. Moreover, the tableaux presented Elizabeth's powers of transformation as

\footnotetext{
${ }^{70}$ Spenser, $12^{\mathrm{v}}$.

${ }^{71}$ Ibid., $14^{\mathrm{v}}$.

${ }^{72}$ See, for example, Levin, 2002, 7, 41, 83.

${ }^{73}$ Berry, 79 .
} 
musical, so that music became an audible sign of Elizabeth's monarchical authority.

First, cornetts sounded in the wood at the top of the hill. ${ }^{74} \mathrm{~A}$ Wild Man appeared claiming to have "followed this sounde, as enchanted, neither knowing the reason why, nor knowing how to bee ridde of it: vnusual to these Woods, and (I feare) to our gods prodigious." ${ }^{75}$ The Wild Man's speech ended predictably with his transformation to civility (this had occurred in many previous progresses, including those at Kenilworth in 1575 and Cowdray in 1591). ${ }^{76}$ However, in this case music initiated the change. Further down the hill, Elizabeth saw Pan attempting to seduce two maidens keeping sheep and sewing samplers. The musical theme reappeared at the end of the device when, upon sight of Elizabeth, Pan declared "And heare I breake my pipe, which Apollo could neuer make me doe; and follow that sounde which followes you." 77 The third and final tableau, while not explicitly musical - at least in the text: if the cornetts were still following Elizabeth, then the metamorphosis may have seemed just as musical as the previous two in performance - showed Ceres being transformed from the "Queene of heaven," the only one on whom Phoebus shines, into a servant of Cynthia-Elizabeth through a whispering in her ears. ${ }^{78}$

Both Pan and the Wild Man represented uncivilized nature, transformed by the presence of the queen. The Pan tableau related to two mythical musical contests: firstly, Pan challenged Apollo to a musical duel and was incorrectly judged the victor by King Midas (who for his lack of judgment was given the ears of an ass by Apollo). ${ }^{79}$ It is presumably this contest that Pan refers to when he claims that Apollo could not make him break his pipe. Secondly, Apollo competed with the satyr, Marsyas. On this occasion, Apollo's lyre, symbolizing reason and civilization, conclusively triumphed over Marsyas's aulos (an ancient Greek reed instrument), representing unbridled emotions. ${ }^{80}$ Peter Davidson and Jane Stevenson interpret the Bisham tableau as an "image of concord" in which "Pan, like the wild man before him, abandons his essential nature, civilized (or emasculated) by one glance from the Queen's eyes. He breaks his pipe; his wild notes give way to the lyre of Apollo;

\footnotetext{
${ }^{74}$ The cornett was a Renaissance wind instrument: long, curved, and made of wood, with a cupped mouthpiece like a brass instrument. It was considered capable of imitating the human voice with its subtlety of expression, but was also loud enough for outside performances.

${ }^{75}$ Barnes, $\mathrm{A} 2^{\mathrm{r}}$.

${ }^{76}$ Gascoigne, $\mathrm{A} 3^{\mathrm{v}}-\mathrm{A} 7^{\mathrm{v}}$; The Speeches, $\mathrm{A} 4^{\mathrm{v}}-\mathrm{B} 2^{\mathrm{v}}$.

${ }^{77}$ Barnes, $\mathrm{A} 4^{\mathrm{r}}$.

${ }^{78}$ Ibid., $\mathrm{A} 4^{\mathrm{r}-\mathrm{v}}$.

${ }^{79}$ Bacon, 1619, 21

${ }^{80}$ Plato, 89-90; Landels, 157.
} 
controlled court music." ${ }^{" 11}$ However, this tableau did not simply present rustic music giving way to courtly music, because Pan submitted, not to Apollo, but to Elizabeth. At the beginning of his tableau, Pan mocked both his and Apollo's music by comparing their respective instruments to farmyard sounds: "You know my suite, loue, my virtue, Musicke, my power, godhead. I cannot tickle the sheepes gutts of a Lute, bydd, bydd, bydd, like the calling of Chickens, but for a Pipe that squeeketh like a Pigg, I am he." ${ }^{82}$ Rather than presenting Pan's music as inferior to Apollo's, the author had Pan denigrate both. Elizabeth's music, not Apollo's, represented harmony and order. Nor did this refer simply to musica instrumentalis, as Elizabeth did not produce this music: instead, she commanded it and it followed her, just as we shall see Elizabeth was credited with bringing heavenly harmony to earth and managing political concord. It was a music that "enchanted" the Wild Man, yet was simultaneously a transformative power of order. ${ }^{83}$ This was how Elizabeth's music could exceed that of Apollo, god of music.

Furthermore, the tableaux assigned to Elizabeth all of the powers traditionally attributed to music. Elizabeth's music could civilize wild men, convert lustful gods to chastity, and make goddesses submit to her authority. These transformations reworked conventional tropes of musical power, such as Orpheus using music to tame wild beasts, and Plato's and Aristotle's beliefs that music could incline people to virtue. They also drew on the magical associations of monarchy itself, such as the belief that the touch of a monarch could cure scrofula. ${ }^{84}$ As musical magic could potentially control all of creation, this dramatic device amplified Elizabeth's power to divine levels. At the Bisham progress, music made Elizabeth's powers audible through the sounding of cornetts: those present could literally sense her authority with their ears. The progress epitomized Elizabeth's aspiration to use the symbolic powers of music to maintain order in her kingdom.

However, the 1590s were a time of increasing political uncertainty: high food prices, unemployment, and heavy taxation caused social unrest, while the court saw increasingly bitter factional disputes and Elizabeth continued to refuse to name her successor. ${ }^{85}$ On the surface, Sir John Davies's poem "To the Queen" appears to praise Elizabeth's pious governance, but these tensions begin to show in the musical metaphors describing Elizabeth's rule:

\footnotetext{
${ }^{81}$ Davidson and Stevenson, 220.

${ }^{82}$ Barnes, $\mathrm{A} 2{ }^{\mathrm{v}}$.

${ }^{83}$ Ibid., $\mathrm{A} 2^{\mathrm{r}}$.

${ }^{84}$ Greene, 637.

${ }^{85}$ Guy.
} 
What Musicke shall we make to you,

To whome the stringes of all mens harts

Make musicke of ten thousand parts

In tune and measure true,

With straines and changes new?

How shall wee fraime a harmony

Worthie your eares, whose princely hands

Keepe harmony in sundry lands,

Whose people divers be

In faction and degree?

Heavens tunes may onely please,

And not such aires as theise.

For you which downe from heaven are sent

Such peace upon the earth to bring,

Have hard the quire of Angells sing,

And all the sphæres consent,

Like a sweete Instrument.

How then should theise harsh tunes you heare,

(Created of the trubled Ayer)

Breed but distast, when they repaire

To your Cælestiall eare?

So that this Center here

For you no Musicke fynds,

But harmony of mynds. ${ }^{86}$

This poem exists only in manuscript, but was probably written after 1594, when Sir John Davies was first presented at court and sworn in as servant-in-ordinary to Elizabeth. ${ }^{87}$ Like John Bennet's song, Davies's poem counterpointed earthly and speculative music. The overall conceit was also similar in asking what kind of music can be worthy of her "Cælestiall eare." Davies's poem argues throughout that Elizabeth took pleasure, not in earthly musical harmony, but in musica mundana - indicating her piety - and musica humana - a sign of her just governance. This distinction is also found in the polemical writings of Protestant writer Stephen Gosson (ca. 1554-1625):

If you will bee good Scholers, and profite well in the Arte of Musicke, shutte your Fidels in their cases, and looke vp to heauen: the order of the Spheres, the vnfallible motion of the Planets, the iuste course of the yeere, and varietie of seasons, the concorde of the Elementes and their qualyties, Fyre, Water, Ayre,

${ }^{86}$ Davies, 1975, 242-43.

${ }^{87}$ Kelsey. 
Earth, Heate, Colde, Moysture and Drought concurring togeather to the constitution of earthly bodies and sustenance of euery creature. The politike Lawes, in well gouerned common wealthes, that treade downe the prowde, and vpholde the meeke, the loue of the King \& his subiectes, the Father and his childe, the Lorde and his Slaue, the Maister and his Man . . . are excellent maisters too shewe you that this is right Musicke, this perfecte harmony. ${ }^{88}$

Davies's musical imagery therefore associated Elizabeth with this "right musicke" and "perfect harmony," rather than with frivolous instrumental or vocal performance. His poem rescued Elizabeth's musical image from the potential criticisms that could be attached to musical women, and appropriated music as an image of piety, virtue, and even power.

Although the opening question of Davies's poem, "What music shall we make to you," seems initially to refer to practical music-making, the poem quickly moves into the realm of political harmony. The first two stanzas make commonplace comparisons between lute strings and heartstrings, punning on the Latin words cor (heart) and cordae (strings). Davies presents Elizabeth as maintaining a diverse harmony of many strings — "musicke of ten thousand parts" in "sundry lands, / Whose people divers be / In faction and degree" - creating music "In tune and measure true." There are echoes of Alciato's Emblematum Liber (1534), in which an image of a lute symbolized an alliance of princes in Italy:

When you are preparing to enter into fresh agreements with your allies It is difficult, except for a man of skill, to tune so many strings And if one string is out of tune or broken, which so easily happens,

All the music of the instrument is lost and its lovely song disjointed. ${ }^{89}$

Such humanist symbolism underpinned poems like Davies's. Alciato's emblem of the lute was well known in Elizabethan England, and its picture was used in a manuscript collection of emblems that (albeit with very different verses) Geffrey Whitney presented to Robert Dudley, Earl of Leicester, in $1585 .^{90}$

The third stanza expands the musical metaphors into the realm of musica mundana. Like Bennet's song, Davies's poem implied that Elizabeth's ears heard heavenly music, imbuing her with divine qualities. The music of the spheres was normally believed to be inaudible to human

${ }^{88}$ Gosson, $8^{\mathrm{r}-\mathrm{v}}$.

${ }^{89}$ Alciato, A2v: "Quo nova cum sociis foedera inire paras. / Difficile est nisi docto homini tot tendere chordas, / Unaque si fuerit non bene tenta fides. / Ruptave (quôd facile est) perit omnis gratia conchae, / Illeque praecellens cantus ineptus erit."

${ }^{90}$ Manning, 1988, 100-01; Manning, 1986; Manning, 1993. 
ears: Gosson exhorts the reader instead to see harmony, "look vp to heaven." Elizabeth's harmonious powers were explained by her ability to hear heavenly harmony, which enabled her to re-create such peace and concord on earth. "Verses of the Queene," addressed to the queen at Christmas, 1602 (and possibly also attributable to Davies), similarly presented Elizabeth as a singing angel, tuning earthly harmonies with her fellow angels:

To see this birth did Angells sweetly singe,

Nowe singes that nest of nightingalls againe,

Joye, peace, goodwill [on earth] to men they bringe,

Of fortie five yeares thus tuninge they remaine.

Long maye they tune that sweete and pleasant songe,

And longe maye she our angell singe amonge. ${ }^{11}$

Evoking the notion of the divinely-appointed monarch, both these verses and Davies's poem presented Elizabeth as heaven-sent. This resonates with images of Elizabeth as God's chosen handmaid that are found in Accession Day hymns, Elizabeth's speeches to Parliament, and her private prayers; as well as with images of the queen as a Protestant champion returning England to the true religion and also supporting Protestants in the Netherlands. ${ }^{92}$

However, alongside these positive images of harmony, Davies juxtaposed "harsh tunes" and "trubled Ayer." These are ambiguous enough to refer both to the musica instrumentalis of the opening line and to function as images of political discord, like the out-of-tune or broken string in Alciato's emblem mentioned above. Lack of knowledge of the context of this poem prevents accurate identification of the troubles referred to in it; however, there was a popular perception of a crisis in the 1590s in the face of economic and social strain, political rivalry, and warfare. The reference to "faction" might evoke the conflicts between Robert Cecil and Robert Devereux, Earl of Essex, particularly after 1595. Their struggles were described in musical terms by John Chamberlain in February 1599: "the jarres continue as they did, yf not worse, by dayly renewing, and our musicke runs so much upon discords, that I feare what harmonie they will make of yt in the end." 93 Similarly "straines and changes new" might refer to the changing personnel of the Elizabethan court following the deaths of the Earl of Leicester (1588), the Earl of Warwick (1590), Sir Water Mildmay (1589), Sir Francis Walsingham (1590), and Sir Christopher Hatton (1591). The

\footnotetext{
${ }^{91}$ Davies, 1975, 307, 424-25.

${ }^{92}$ Sharpe, 329-31, 341-44, 351-52, 397-99.

${ }^{93}$ Chamberlain, 67.
} 
membership of the Privy Council and the political elite underwent a significant shift after twenty years of stability under the Earl of Leicester and Lord Burghley, who died in 1598. ${ }^{94}$

The "harsh tunes" of Davies's poem might be interpreted as those of warfare, as England was at war with Spain (1585-1604), with further forces committed in the Netherlands (from 1585), France (1589-94), and, later, in Ireland (1594-1603). This was a marked change from Elizabeth's previous policy of non-intervention in the problems of Continental Europe and the nearly thirty years of peace this had brought prior to 1585. ${ }^{95}$ Similarly, the "trubled Ayer" could evoke the famine and sharp rises in food prices cased by four successive harvest failures in 1594-97, the outbreaks of plague and influenza, the heavy taxation being levied to pay for war, large-scale unemployment as overseas trade diminished, increased crime and vagrancy, and fears of civil unrest that threatened to materialize in the Oxfordshire Rising of $1596 .^{96}$ Davies may also have had in mind the uncertainties caused by Elizabeth's refusal to name a successor, as numerous tracts circulated discussing a possible thirteen domestic and foreign candidates for the succession. ${ }^{97}$ Davies addressed this topic in Orchestra or A Poeme of Dauncing (1596), particularly in the manuscript version, which celebrates order throughout nature (here imagined primarily through dance rather than music) but pointedly omits reference to political harmony. Even in the published version - into which an image of political concord was inserted - Penelope's indecision over Antinous's persuasion to dance remained as a symbolic rejection of order. ${ }^{98}$

Although Davies's final lines evoke the "harmony of mynds" - perhaps suggesting the loyalty and unity of English subjects - the poem does not reconcile these troubling references to discord. Rather, Elizabeth's potential as a bringer of harmony is juxtaposed against the realities of unrest. In this light, the claim of the third stanza that Elizabeth was "downe from heaven ... sent / such peace upon the earth to bring" might be read, not as praise, but as criticism that Elizabeth is failing in her duty to God and her kingdom.

Davies was not the only poet in the 1590s to mix images of harmony and discord in a way that suggested the tensions of the period. Thomas Churchyard (1523?-1604) presented Elizabeth as personified through

\footnotetext{
${ }^{94}$ Guy, 2-4; MacCaffrey, 12-13.

${ }^{95}$ MacCaffrey, 3-9; Guy, 1.

${ }^{96}$ Archer, 9-14; Guy, 8-11.

${ }^{97}$ Hurstfield; Myers; Doran, 2004.

${ }^{98}$ Brink.
} 
music in A Musicall Consort of Heauenly Harmonie . . called Churchyards Charitie (1595):

$\mathrm{O}$ treble Queen, the sweete and highest part

That we like best, and shrillest voice doth sound

The onely meane, to shew deepe musicks art

Where all the skill; of well set song is found.

Grant silly man, a grace that meanes to sing

Of heaunly loue, and of none other thing.

He sings of peace, a song should lull asleep

The fellest feends, and fearfull bugs below. ${ }^{99}$

As an author of civic entertainments for Elizabeth's progresses, and also a frequent writer for the popular press in the form of broadside ballads and poetic collections, Churchyard was a different type of poet than Spenser or Davies. Churchyard drew on the musical imagery through which Elizabeth was increasingly portrayed in the 1590 s, but adapted its themes to be accessible to a wider audience via print by abandoning the more learned topics of the music of the spheres or the classical gods. Instead, through a series of puns, Elizabeth becomes treble, mean, and bass: "treble Queen," "the onely meane," and "deepe musicks art," deep referring both to pitch and the exceptional quality of the art of music. These terms refer to the upper, middle, and lower parts of a polyphonic song, so she therefore had "all the skill of well set song." Elizabeth represented the total harmony: as queen she was the highest part and the one who ordered the harmony of the lower estates. Furthermore, the song that she taught men to sing was of "peace" and "heaunly love." Yet as we have seen, 1595 was hardly a time of peace and love; "fellest feends" and "fearfull bugs" introduced a sense of discord so that the juxtaposition of harmonious image and dissonant reality drew attention to the gap between Churchyard's royal praise and the turbulent political situation.

Churchyard's poem is also an example of how courtly tropes of Elizabeth's harmonious governance could spread into publications aimed at a broader audience. These tended to be less directly connected to Elizabeth's musicality than in Churchyard's poem, and focused instead on the idealized harmony of English subjects. Such poetic visions of harmonious subjects were closely related to her image as bringer of concord. Many were produced in literature for the annual celebrations of Elizabeth's Accession Day (November 17), such as George Peele's Anglorum

\footnotetext{
${ }^{99}$ Churchyard, $\mathrm{A}^{\mathrm{r}}$.
} 
Feriae (1595). Peele described how "Londons Shepherde Gardian of his flock":

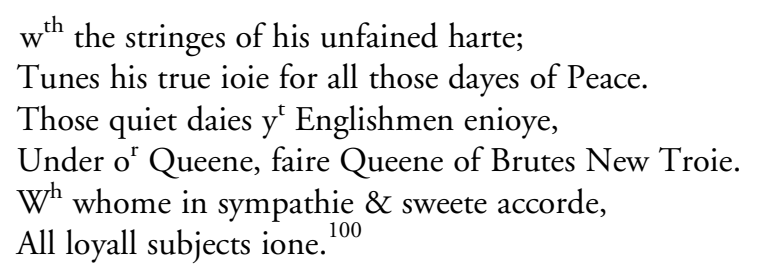

Peele represents the unity of Elizabeth's subjects with the same imagery of heartstrings as found in Davies's poem and Alciato's emblem. Elsewhere in the poem he describes Londoners singing in praise and thanks for their queen: Elizabeth is the inspiration for both music-making and harmony. Such imagery was common, especially in Accession Day literature, and it was concordant with portrayals of the mutual love between Elizabeth and her subjects from throughout her reign. ${ }^{101}$ However, the disjunction between the poem and political reality could not be more marked. ${ }^{102}$ London in 1595 had seen unrest on Shrove Tuesday, riots over the price of fish and butter, and a march of a thousand apprentices on Tower Hill that resulted in the city being placed under martial law for the rest of the summer. ${ }^{103}$

Such metaphors of Elizabethan harmony became most marked in the troubled times of the 1590s. Various explanations are possible. In widelydistributed literature such as the poems by Peele or Churchyard, this imagery may have aimed at encouraging future harmony and stability, in contrast to the current state of politics. Conversely, they may reveal continued widespread affection for Elizabeth despite the uneasy times, just as Davies was content to glorify Elizabeth in his Hymnes to Astraea in 1599. Yet his "What musicke shall we make to you" simultaneously praised and criticized Elizabeth, seeming to celebrate Elizabeth's abilities as a ruler yet also expressing discontent at the numerous political discords. $\mathrm{B} 3^{\mathrm{v}}-\mathrm{B} 4^{\mathrm{r}}$

${ }^{100}$ Peele, $\mathrm{C}^{\mathrm{v}}-\mathrm{C}^{\mathrm{r}}$. Similar imagery of the harmonious kingdom can be found in Kyffin,

${ }^{101}$ Sharpe, 354-56, 417-18, 462-66.

${ }^{102}$ Davidson and Stevenson, 220, note a similar incongruity between image and political reality in their interpretation of the Bisham entertainment of 1592: the continued use of the fertile pastoral imagery of her youth despite her age, and images of concord despite warfare and strained domestic politics.

${ }^{103}$ Archer, 1-2. 


\section{CONCLUSION}

Elizabeth's musical image drew on both the sensual and the rational connotations of music. From the earliest years of her reign, she used the intimacy of musical performances to fashion relationships with foreign ambassadors, and used music's relation to desirability and youth to foster an illusion of changelessness and eternal beauty. From the 1580s the musical identity of Elizabeth created by her poets, musicians, and courtiers became an image of power and even divinity, which subverted traditional stereotypes of female weakness and sought to present Elizabeth as controlling political harmony. As Elizabeth's natural body grew visibly older and weaker — she turned sixty years old in 1593 - as England remained at war with Spain, and as social and economic problems mounted, it was increasingly important to represent her royal power as stronger than ever. Poets could amplify Elizabeth's royal powers through musical metaphors that evoked political power over men and nature, and that emphasized the shared heavenly source of both harmony and divinely appointed monarchy. Such images of concord were increasingly distant from the political reality, and some poets adapted metaphors of harmony to register their discontent. Nor was it only musical imagery that was engaged with the turbulent politics of this period, but songs too: Jeremy Smith has recently interpreted Thomas Morley's Triumphes of Oriana (1601) as initially intended to praise, not Elizabeth (as had been previously assumed), but Anne (1574-1619), wife of James VI of Scotland, in support of his claim as heir to the English throne. ${ }^{104}$ Nevertheless, many poets continued to emphasize the unity of English subjects, and to fashion a vision of Elizabeth as bringer of peace and concord.

Although her sister and predecessor Mary Tudor and her cousin Mary Queen of Scots were both highly praised for their musical talents, their music-making does not seem to have had such a political role, and there was no such accompanying use of music in royal image-making. Musical imagery did, of course, occur in pageantry across Europe. The Medici wedding festivities in Florence in 1589 - celebrating the marriage of Grand Duke Ferdinando I de' Medici and French Princess Christine de Lorraineincluded intermedi based on the theme of the power of musical harmony to influence gods and men, including one that illustrated the notion of the harmony of the spheres with the sirens of each sphere singing wedding blessings. ${ }^{105}$ In France, Henri IV (1553-1610) was greeted by the musical heroes Amphion and Orpheus and the god Apollo during royal entries into

\footnotetext{
${ }^{104}$ Smith, 523-24, 548-50.

${ }^{105}$ Saslow, 30-33, 151-58.
} 
Lyon (1595) and Rouen (1596), where music was used to signify social harmony and lasting peace after civil war. ${ }^{106}$ Several other examples could be given: however, such musical images were rarely applied as frequently or directly to the person of the monarch (especially to a queen), nor with the same close connection between speculative musical harmony and the monarch's practical musicianship. The musical imagery surrounding Elizabeth was intimate. It frequently evoked both her personal musical talents and her body, as when Sir John Davies praised her "worthy eares," "princely hands," and her mind, or John Bennet's song recalled her "sacred ears" and "skill." 107 Furthermore, representations of Elizabeth's political harmony were combined with stereotypical notions of the sensual delights of women's musical performances. We see this when Elizabeth's harmonious rule is described as "sweet pleasure" or enchantment, and Elizabeth as "the sweete and highest part / that we like best." ${ }^{\text {"108 }}$ Even the more indirect images of Elizabeth's loyal and harmonious subjects were paired with descriptions of them singing and making music in her honor. This interconnection of practical and speculative harmony was central to Elizabeth's musical image.

Such musical imagery simultaneously emphasized Elizabeth as a woman while attributing to her the political power, constancy, and rationality conventionally granted only to men. By blending the talents of Elizabeth's natural body with those of her political body, and by merging practical musicianship with speculative harmony, Elizabeth and her courtiers used music to create political authority in an age when queenship could still be contentious.

St John's College, University of OXford

\footnotetext{
${ }^{106}$ Van Orden, 176-82.

${ }^{107}$ Davies, 1975, 242-43; Davies, 1599, 19; Bennet, $9^{\mathrm{v}}\left(17790,5^{\mathrm{v}}-6^{\mathrm{r}}\right)$.

${ }^{108}$ Davies, 1599, 19; Barnes, $A 2^{\mathrm{r}}$; Churchyard, $\mathrm{A}^{\mathrm{r}}$.
} 


\section{Bibliography}

Alciato, Andrea. Emblematum Liber. Augsburg, 1534. www.emblems.arts.gla. ac.uk/alciato/books.php?id $=\mathrm{A} 34 \mathrm{a} \& \mathrm{o}=$ (accessed 13 February 2010).

Archer, Ian. The Pursuit of Stability: Social Relations in Elizabethan London. Cambridge, 1991.

Ashbee, Andrew, and David Lasocki. A Biographical Dictionary of English Court Musicians 1485-1715. 2 vols. Aldershot, 1998.

Austern, Linda Phyllis. "'Sing Againe Syren': The Female Musician and Sexual Enchantment in Elizabethan Life and Literature." Renaissance Quarterly 42.3 (1989): 420-48.

. "Alluring the Auditorie to Effeminacie': Music and the Idea of the Feminine in Early Modern England." Music \& Letters 74 (1993): 343-54.

"Women's Musical Voices in Sixteenth-Century England." Early Modern Women: An Interdisciplinary Journal 3 (2008): 127-52.

Bacon, Francis. The Wisedome of the Ancients, Written in Latine by the Right Honourable Sir Francis Bacon Knight, Baron of Verulam and Lord Chancelour of England. Done into English by Sir Arthur Gorges Knight. London, 1619.

. The Works of Francis Bacon. Ed. James Spedding, Robert Leslie Ellis, and Douglas Denon Heath. 14 vols. London, 1857-74.

Barnes, Joseph, ed. Speeches Deliuered to Her Maiestie this Last Progresse at the Right Honorable the Lady Russels, at Bissam, the Right Honorable the Lorde Chandos at Sudley, at the Right Honorable the Lord Norris, at Ricorte. Oxford, 1592.

Bates, Catherine. The Rhetoric of Courtship in Elizabethan Language and Literature. Cambridge, 1992.
Bennet, John. "Elisa Her Name Gives Honor." In British Library: Add MSS 17786-91, $9^{\mathrm{v}}\left(17790,5^{\mathrm{v}}-6^{\mathrm{r}}\right)$.

Berry, Philippa. Of Chastity and Power: Elizabethan Literature and the Unmarried Queen. London, 1989.

Brewer, J. S., R. H. Brodie, and James Gairdner, eds. Letters and Papers, Foreign and Domestic of the Reign of Henry VIII. 21 vols. London, $1864-1920$

Brink, J. R. "Sir John Davies's Orchestra: Political Symbolism and Textual Revisions." Durham University Journal, n.s., 41 (1980): 195-201.

Burton, Robert. The Anatomy of Melancholy What It Is. With All the Kindes, Causes, Symptomes, Prognostickes, and Seuerall Cures of It. In Three Maine Partitions with Their Seuerall Sections, Members, and Subsections. Philosophically, Medicinally, Historically, Opened and Cut Vp. By Democritus Iunior. With a Satyricall Preface, Conducing to the Following Discourse. Oxford, 1621.

Byrd, William. Cantiones Sacrae (1575). Ed. Craig Monson. London, 1977.

Calogero, Elena Laura. "'Sweet aluring harmony': Heavenly and Earthly Sirens in Sixteenth-Century Literary and Visual Culture." In Music of the Sirens, ed. Linda Phyllis Austern and Inna Naroditskaya, 140-75. Bloomington, 2006.

Castiglione, Baldassarre. The Courtyer of Count Baldessar Castilio Diuided into Foure Bookes. Very Necessary and Profitable for Yonge Gentilmen and Gentilwomen Abiding in Court, Palaice or Place, Done into English by Thomas Hoby. London, 1561.

Challoner, Francis. "To Sir Thomas Challoner, 18 December 1562." In Secretaries of State: State Papers Foreign, Elizabeth I, 1558-1577. 
SP70/66, 92 $-96^{\mathrm{v}}$. The National Archives of the UK. http://go. galegroup.com $/ \mathrm{mss} /$ i.do? \&id $=$ Gale $\%$ CMC431 $1401503 \& v=2.1 \& v=$ britlib \&it $=\mathrm{r} \& \mathrm{p}=\mathrm{SPOL} \& \mathrm{sw}=\mathrm{w} \quad$ (accessed 26 February 2010).

Chamberlain, John. The Letters of John Chamberlain. Ed. Norman Egbert McClure. Philadelphia, 1939.

Chambers, E. K. The Elizabethan Stage. 4 vols. Oxford, 1945.

Churchyard, Thomas. A Musicall Consort of Heauenly Harmonie (Compounded Out of Manie Parts of Musicke) Called Churchyards Charitie. London, 1595.

Clapham, John. Elizabeth of England: Certain Observations Concerning the Life and Reign of Queen Elizabeth by John Clapham. Ed. Evelyn Plummer Read and Conyers Read. Philadelphia, 1951.

Craig-McFeely, Julia. "The Signifying Serpent: Seduction by Cultural Stereotype in Seventeenth-Century England." In Music, Sensation and Sensuality, ed. Linda Phyllis Austern, 299-317. London, 2002.

Davidson, Peter, and Jane Stevenson. "Elizabeth I's Reception at Bisham (1592): Elite Women as Writers and Devisers." In The Progresses, Pageants, and Entertainments of Queen Elizabeth I, ed. Jayne Elisabeth Archer, Elizabeth Goldring, and Sarah Knight, 207-26. Oxford, 2007.

Davies, Sir John. Hymnes of Astraea in Acrosticke Verse. London, 1599.

. The Poems of Sir John Davies. Ed. Robert Krueger. Oxford, 1975.

Doran, Susan. Monarchy and Matrimony: The Courtships of Elizabeth I. London, 1996.

. "Three Late-Elizabethan Succession Tracts." In The Struggle for the Succession (2004), 100-17.

Dowland, John. The Second Booke of Songs or Ayres, of 2. 4. and 5. Parts with
Tableture for the Lute or Orpherian, with the Violl de Gamba. Composed by Iohn Dowland Batcheler of Musick, and Lutenist to the King of Denmark: Also an Excelent Lesson for the Lute and Base Viol, Called Dowlands Adew. London, 1600.

Drayton, Michael. Idea the Shepheards Garland Fashioned in Nine Eglogs. Rowlands Sacrifice to the Nine Muses. London, 1593.

Ellis-Fermor, Una. The Frontiers of Drama. $3^{\text {rd }}$ ed. London, 1964.

Elyot, Sir Thomas. The Boke Named the Gouernour, Deuysed by Syr Thomas Elyot Knight. London, 1537.

Evans, Gwynne Blakemore. The Riverside Shakespeare. $2^{\text {nd }}$ ed. Boston, 1997.

Fantazzi, Charles. "Vives, Juan Luis (1492/ 3-1540)." In Oxford Dictionary of National Biography. Oxford, 2004; online edn, 2008. www.oxforddnb. com/view/article/28337 (accessed 17 February 2009).

Fischlin, Daniel. "The Performance Context of the English Lute Song, 1596-1622." In Performance on the Lute, Guitar and Vihuela: Historical Practice and Modern Interpretation, ed. Victor Anand Coelho, 47-71. Cambridge, 1997.

Fitzwilliam, William, Earl of Southampton. "About Katharine Howard (5 Nov 1541)." State Papers, Henry VIII: General Series. National Archives of the UK, SP $1 / 167,110^{\mathrm{r}}-13^{\mathrm{r}}$. http:// go.galegroup.com $/ \mathrm{mss} / \mathrm{i} . \mathrm{do}$ ? \&id= GALE\%7CMC4302781332\&v= $2.1 \& u=$ oxford $\& i t=r \& p=S P O L \&$ $s \mathrm{w}=\mathrm{w}$ (accessed 23 February 2010).

Fox, Adam. Oral and Literate Culture in England 1500-1700. Oxford, 2000.

Gascoigne, George. The Pleasauntest Workes of George Gascoigne Esquyre newlye compyled into one volume, that is to say: his flowers, hearbes, weedes, the fruites of warre, the comedie called Supposes, the tragedie of Iocasta, the 
Steele glasse, the complaint of Phylomene, the storie of Ferdinando Ieronimi, and the pleasure at Kenelworth Castle. London, 1587.

Gosson, Stephen. The Schoole of Abuse Conteining a Plesaunt Inuectiue Against Poets, Pipers, Plaiers, Iesters, and Such Like Caterpillers of a Comonwelth; Setting Vp the Hagge of Defiance to their Mischienous Exercise, Ouerthrowing their Bulwarkes, by Prophane Writers, Naturall Reason, and Common Experience: a Discourse as Pleasaunt for Gentlemen that Fauour Learning, as Profitable for All that Wyll Follow Virtue. London, 1579.

Greene, Thomas. "Magic and Festivity at the Renaissance Court." Renaissance Quarterly 40.4 (1987): 636-59.

Guy, John. "The 1590s: The Second Reign of Elizabeth I?" In The Reign of Elizabeth I: Court and Culture in the Last Decade, ed. John Guy, 1-19. Cambridge, 1995.

Harington, Sir John. Nuge Antique: Being a Miscellaneous Collection of Original Papers, in Prose and Verse; Written During the Reigns of Henry VIII, Edward VI, Queen Mary, Elizabeth, and King James. Ed. Henry Harington and Thomas Park. 2 vols. London, 1804.

Helms, Dietrich. "Henry VIII's Book: Teaching Music to Royal Children." Musical Quarterly 92 (2009): 118-35.

Herries, Lord. Historical Memoirs of the Reign of Mary Queen of Scots, and a Portion of the Reign of King James the Sixth. Ed. R. Pitcairn. Edinburgh, 1836.

Hollander, John. The Untuning of the Sky: Ideas of Music in English Poetry 1500-1700. Princeton, 1961.

Holman, Peter. Four and Twenty Fiddlers: The Violin at the English Court, 1540-1690. Oxford, 1993.

Hotson, Leslie. The First Night of Twelfth Night. New York, 1954.

Hurstfield, Joel. "The Succession Struggle in Late Elizabethan England." In
Freedom, Corruption and Government in Elizabethan England, ed. Joel Hurstfield, 104-34. London, 1973.

Kelsey, Sean. "Davies, Sir John (bap. 1569, d. 1626)." In Oxford Dictionary of National Biography. Oxford, 2004; online ed., 2008. www.oxforddnb. $\mathrm{com} /$ view/article/7245 (accessed 31 March 2009).

Kilroy, Gerard, ed. The Epigrams of Sir John Harington. Farnham, 2009.

Klarwill, Victor, ed. Queen Elizabeth and Some Foreigners: Being a Series of Hitherto Unpublished Letters from the Archives of the Hapsburg Family. London, 1928.

Knox, John. The First Blast of the Trumpet Against the Monstruous Regiment of Women. Geneva, 1558.

Kyffin, Maurice. The Blessednes of Brytaine, or A Celebration of the Queenes Holyday Conteining, a Breefe Rehersall, of the Inestimable Benefits, Generally Had o Enioyed, Not Only All England Ouer, But Also in Forrein Partes, Through the Gracious Bountie, and Incomparable Blessed Rule of Our Royall Queene Elizabeth. Composed, and Set Foorth, in Due Reuerence, \& Ioyfull Memoriall, of Her Maiesties Present Entrance into the Thirtieth Yeere of Her Most Triumphant Raigne, with Hartie Prayer, for the Long Continuing, and Prosperous Preseruing of the Same: By Maurice Kyffin. London, 1587.

Landels, John. Music in Ancient Greece and Rome. London, 1999.

Lasocki, David. The Bassanos: Venetian Musicians and Instrument Makers in England, 1531-1665. Aldershot, 1995.

Levin, Carole. The Heart and Stomach of a King: Elizabeth I and the Politics of Sex and Power. Philadelphia, 1994. . The Reign of Elizabeth I. Basingstoke, 2002.

Lloyd, Lodowick. The Pilgrimage of Princes, Penned Out of Sundry Greeke and 
Latine Aucthours, by Lodowicke Lloid Gent. London, 1573.

MacCaffrey, Wallace. Elizabeth I: War and Politics, 1588-1603. Princeton, 1992.

Maisse, André Hurault de. A Journal of All That was Accomplished by Monsieur De Maisse, Ambassador in England from King Henri IV to Queen Elizabeth . . . 1597. Ed. Robert Arthur Jones and G. B. Harrison. London, 1931.

Manning, John. "Continental Emblem Books in Sixteenth-Century England: The Evidence of Sloane MS. 3794." Emblematica 1 (1986): 1-11.

. "Geffrey Whitney's Unpublished Emblems: Further Evidence of Indebtedness to Continental Traditions." In The English Emblem and the Continental Tradition, ed. Peter M. Daly, 83-107. New York, 1988.

. "An Unedited and Unpublished Sixteenth-Century English Translation of Some Alciato Emblems: British Library Additional MS. 61822." Emblematica 7 (1993): 181-82.

Melville, James. Memoirs of Sir James Melville of Halhill, 1535-1617. Ed. A. Francis Steuart. London, 1929.

Montrose, Louis. “'Shaping Fantasies': Figurations of Gender and Power in Elizabethan Culture." Representations 2 (1983): 61-94.

. The Subject of Elizabeth: Authority, Gender, and Representation. Chicago, 2006.

Mulcaster, Richard. Positions Wherin those Primitiue Circumstances be Examined, which are Necessarie for the Training Vp of Children, Either for Skill in Their Booke, Or Health in Their Bodie. Written by Richard Mulcaster, Master of the Schoole Erected in London Anno. 1561. in the Parish of Sainct Laurence Powntneie, by the Worshipfull Companie of the Merchaunt Tailers of the Said Citie. London, 1581.
Myers, Nick. "The Gossip of History: The Question of the Succession in the State Papers." In The Struggle for the Succession (2004), 49-64.

Nichols, John. The Progresses and Public Processions of Queen Elizabeth: Among which are Interspersed other Solemnities, Public Expenditures, and Remarkable Events, during the Reign of that Illustrious Princess. London, 1823.

Peele, George. Anglorum Feriae Englandes Hollydayes Celebrated the 17th Novemb. Last, 1595, Beginning Happyly the 38 Yeare of the Reigne of our Soveraigne Ladie Queene Elizabeth by George Peele Mr of Arte in Oxforde. 1595. Reprint, London, 1840.

Plato. The Republic. Trans. Tom Griffith. Ed. G. R. F. Ferrari. Cambridge, 2000.

Pollack, Janet. "Princess Elizabeth Stuart as Musician and Muse." In Musical Voices of Early Modern Women: ManyHeaded Melodies, ed. Thomasin LaMay, 399-424. Aldershot, 2005.

Pontaymeri, Alexandre de. A Womans Woorth, Defended Against all the Men in the World Proouing them to be More Perfect, Excellent, and Absolute in all Vertuous Actions, then any Man of what Qualitie Soeuer. Written by One that Hath Heard Much, Seene Much, but Knowes a Great Deale More. London, 1599.

Poulton, Diana. "The Favourite Singer of Queen Elizabeth I." The Consort 14 (1957): 24-27. . John Dowland. London, 1982.

The Praise Of Musicke Wherein Besides The Antiquitie, Dignitie, Delectation, \& Vse Thereof in Ciuill Matters, is Also Declared the Sober and Lawfull Vse of the Same in the Congregation and Church of God. Oxford, 1586.

Prizer, William. "Una 'Virtù Molto Conveniente a Madonna': Isabella d'Este as a Musician." The Journal of Musicology 17 (1999): 10-49. 
Salomon, Nanette. "Positioning Women in Visual Convention: The Case of Elizabeth I." In Attending to Women in Early Modern England, ed. Betty Travitsky and Adele F. Seeff, 64-95. Newark, 1994.

Salter, Thomas. A Mirrhor Mete for All Mothers, Matrones, and Maidens, Intituled the Mirrhor of Modestie No Lesse Profitable and Pleasant, Then Necessarie to Bee Read and Practiced. London, 1579.

Saslow, James. The Medici Wedding of 1589: Florentine Festival as Theatrum Mundi. New Haven, 1996.

Shakespeare, William. The Norton Shakespeare. Ed. Stephen Greenblatt, Walter Cohen, Jean E. Howard, and Katharine Eisaman Maus. New York, 1997.

Troilus and Cressida. Ed. Anthony Dawson. Cambridge, 2003.

Sharpe, Kevin. Selling the Tudor Monarchy: Authority and Image in Sixteenth Century England. New Haven, 2009.

Smith, Jeremy. "Music and Late Elizabethan Politics: The Identities of Oriana and Diana." Journal of the American Musicological Society 58 (2005): 507-58.

The Speeches and Honorable Entertainment Giuen to the Queenes Maiestie in Progresse, at Cowdrey in Sussex, by the Right Honorable the Lord Montacute. London, 1591.

Spenser, Edmund. The Shepheardes Calender Conteyning Twelue Aeglogues Proportionable to the Twelue Monethes. Entitled to the Noble and Vertuous Gentleman Most Worthy of All Titles Both of Learning and Cheualrie $M$. Philip Sidney. London, 1579.

Stevenson, Joseph, et al., eds. Calendar of State Papers Foreign, Elizabeth
1558-1589. 23 vols. London, 1863-1950.

Strong, Roy. The Cult of Elizabeth: Elizabethan Portraiture and Pageantry. London, 1977.

. The English Renaissance Miniature. London, 1983.

The Struggle for the Succession in Late Elizabethan England: Politics, Polemics and Cultural Representations. Ed. JeanChristophe Mayer. Montpellier, 2004.

Treitler, Leo, ed. Strunk's Source Readings in Music History. New York, 1998.

Van Orden, Kate. Music, Discipline and Arms in Early Modern France. Chicago, 2005.

Vives, Juan Luis. A Verie Fruitfull and Pleasant Booke, Called the Instruction of a Christian Woman. Made First in Latin, by the Right Famous Cleark M. Lewes Viues, and Translated out of Latine into Englishe, by Richard Hyrde. $8^{\text {th }}$ ed. London, 1585.

Wegman, Rob. The Crisis of Music in Early Modern Europe 1470-1530. New York, 2005.

Wells, Robin Headlam. Elizabethan Mythologies: Studies in Poetry, Drama and Music. Cambridge, 1994.

Württemberg, Frederick, Duke of, and Prince Lewis Frederick. England as Seen by Foreigners in the Days of Elizabeth and James the First, Comprising Translations of the Journals of the Two Dukes of Wirtemberg [Frederick I and Prince Lewis Frederick] in 1592 and 1610. Ed. William Brenchley Rye. London, 1865.

Young, Alan. Tudor and Jacobean Tournaments. London, 1987.

Zecher, Carla. "The Gendering of the Lute in Sixteenth-Century French Love Poetry." Renaissance Quarterly 53.3 (2000): 769-91. 